\title{
Agroforestry coffee production increased by native shade trees, irrigation, and liming
}

\author{
Virginie Boreux ${ }^{1,2}$ (D) Philippe Vaast $^{3}$ - Lavin P. Madappa ${ }^{4}$. \\ Kushalappa G. Cheppudira ${ }^{4}$. Claude Garcia ${ }^{5}$. Jaboury Ghazoul ${ }^{1}$
}

Accepted: 14 June 2016 / Published online: 6 July 2016

(C) INRA and Springer-Verlag France 2016

\begin{abstract}
Agroforestry systems usually include a high density and diversity of shade trees. Such systems often have a large diversity of fauna and flora and provide local and regional ecosystem services. Shade trees are, however, being removed to increase crop production in many tropical regions. There is little knowledge on the effect of shade trees on crop production in the context of trade-offs with other management practices. We therefore compared the benefits of exotic versus native shade trees on coffee production. We evaluated the importance of shade tree management for crop production in the context of management practices. Management practices included fertilization, liming, coffee pruning, weeding, and irrigation in 113 coffee agroforests in Kodagu, India, over a wide range of shade tree density, tree species diversity, and shade cover. We studied, in particular, Grevillea and nonGrevillea shade trees, the latter including mostly native tree species. Results show that a rise of 100 non-Grevillea shade
\end{abstract}

Virginie Boreux

virginie.boreux@nature.uni-freiburg.de

1 Ecosystem Management, Institute of Terrestrial Ecosystems, ETH Zürich, Universitaetstrasse 16, 8092 Zurich, Switzerland

2 Present address: Institute for Earth and Environmental Sciences, Nature Conservation and Landscape Ecology, University of Freiburg, Tennenbacherstr. 4, 79106 Freiburg, Germany

3 UMR Eco\&Sols - Ecologie Fonctionnelle \& Biogéochimie des Sols \& Agroécosystèmes (SupAgro-CIRAD-INRA-IRD), CIRAD, 2 Place Viala, 34060 Montpellier, France

4 College of Forestry, Ponnampet, University of Agricultural and Horticultural Sciences Shimoga, Ponnampet 571216, India

5 Forest Management and Development, Institute of Terrestrial Ecosystems, ETH Zürich, Universitaetstrasse 16, 8092 Zurich, Switzerland tree per hectare increased production of berries by $5.6 \%$ and larger beans by $6.25 \%$. Irrigation and liming increased berry production respectively by 16 and $20 \%$. These management interventions are likely to offset the relatively small negative effect of reducing shade density of non-Grevillea trees on coffee production. Recommendations based on an understanding of shade tree management alone can be misleading with regard to crop production.

Keywords Coffea canephora $\cdot$ Ecosystem services · Exotic species $\cdot$ Grevillea robusta $\cdot$ India $\cdot$ Kodagu $\cdot$ Management practices $\cdot$ Trade-offs

\section{Introduction}

Agroforestry systems have been described in terms of structural complexity and management practices, with the recognition that increasingly intensive management is associated with reduced structural complexity (Beer et al. 1998). Intensively managed systems receive high inputs of fertilizers and pesticides to promote crop production and usually harbor less shade tree diversity. Shade cover in intensive systems might be provided by a single canopy layer, which is often composed of a few or even only one species. This benefits production (Muschler and Wintgens 2009) at the expense of biodiversity (Perfecto et al. 1997; Somarriba et al. 2004). Less intensive agroforestry systems typically retain a multi-layered canopy resulting from a diverse mix of multi-aged trees, composing a mosaic of niches favoring high biological diversity (Mas and Dietsch 2003; Perfecto et al. 1996). Such structural complexity and species diversity provide a range of ecosystem services that can enhance productivity, such as pollination (Klein et al. 2003) and pest control (Kellermann et al. 2008). Despite this, however, less intensive management remains 
often less productive in terms of yield and profitability (see Campanha et al. 2005; Somarriba et al. 2004 for coffee). This has led to a discrepancy between the priorities of farmers and those of conservationists (Garcia et al. 2010; Kitti et al. 2009). Farmers often choose to reduce shade and replace the original shade trees with faster growing exotic species (Nath et al. 2011), despite recent research advocating diverse and shaded agroforestry systems to conserve biodiversity and secure ecosystem services (Borkhataria et al. 2012; Harvey et al. 2008; Perfecto et al. 1996). Moreover, while many studies have investigated the role of shade and shade trees in agroforestry production, particularly coffee (e.g., Beer et al. 1998; Campanha et al. 2005; Soto-Pinto et al. 2000), a few take into account the broader management context, including fertilization or water management, or distinguish between the origins of the species pool forming the canopy. Therefore, there is a need to evaluate the relevance of retaining shade trees given the broad management practices that affect crop production.

We propose to explore the question using the welldocumented coffee agroforestry systems of Kodagu in the Western Ghats, India. Here, coffee farmers have maintained a remarkably diverse canopy cover to shade their Arabica (Coffea arabica) and Robusta (Coffea canephora var robusta) plantations. Coffee farmers, however, tend to replace this biodiversity rich cover with a simplified monospecific cover of one exotic species, Grevillea robusta, which is a fast growing timber species imported from Australia (Garcia et al. 2010; Nath et al. 2011). In our study, shade trees were separated into two categories: Grevillea and non-Grevillea, the latter category encompassing mostly native tree species.

In this study, we hypothesize not only that (i) shade contributes less to crop yield enhancement than other management practices, but also that (ii) Grevillea shade trees have a less positive effect on Robusta coffee than other shade tree species (native or exotic). To this effect, we investigated the contribution to Robusta coffee production of different management practices, in particular irrigation, liming, fertilizer and manure addition, and shade management. Shade composition and, particularly, the presence and local abundance of G. robusta are used to address the second hypothesis (Fig. 1).

\section{Material and methods}

\subsection{Site selection}

The study was carried out in the district of Kodagu (Karnataka, India) located on the eastern slope of the Western Ghats, which is a recognized biodiversity 'hotspot' (Fig. 2). The region mainly produces $C$. canephora (70 \% of the Kodagu coffee production) in agroforestry systems, varying widely in their

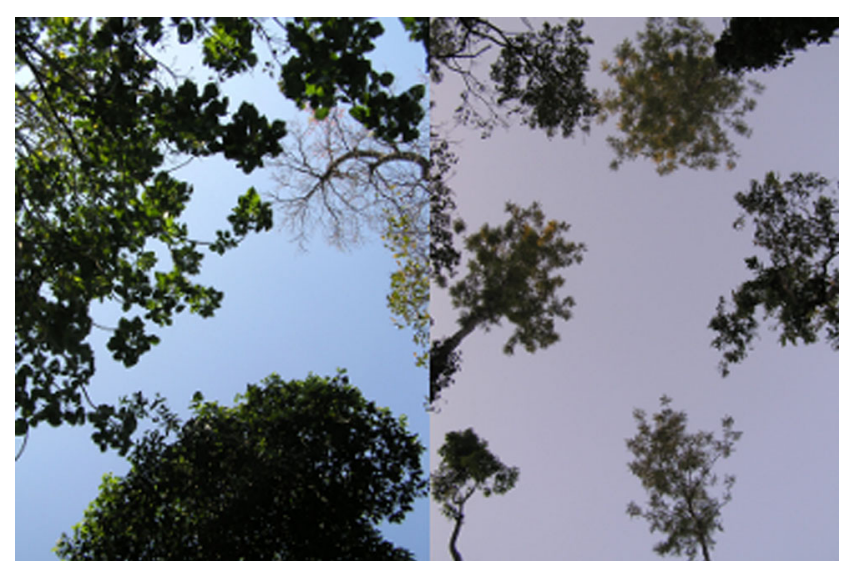

Fig. 1 Canopies of shade trees in Robusta coffee agroforests in Kodagu, India. The left picture shows the canopy of a traditional agroforest, with several species of shade trees of dense foliage. The right picture shows the canopy of an intensified agroforest, where Grevillea robusta dominates (pictures taken in January 2009)

management intensity. Major management practices include soil management (NPK fertilization, addition of manure and lime, hoeing), irrigation to stimulate timely coffee flowering, pruning of coffee trees, and weeding to facilitate access to the estate. Shade cover and shade tree density are also managed. Coffee plantations in Kodagu have traditionally retained some of the original forest trees, which provide structurally complex and species diverse canopy layers. In the past two decades, farmers have been replacing such trees with fast growing exotic species, primarily G. robusta, which provides support for both pepper vines and short rotation timber (Garcia et al. 2010). In 2008, we collected data on coffee management and productivity from 113 plantations of C. canephora (henceforth 'sites') in South Kodagu. All sites were distant from each other by at least $1 \mathrm{~km}$. The sites were selected so that coffee trees were 20 to 40 years old to minimize variation attributable to tree age.

\subsection{Management practices}

All 113 farmers were interviewed on their agricultural practices. The interviews were conducted in Kannada (local language) or English by a trained field assistant. Information was collected on the following management practices implemented over the annual production cycle: frequency of application and amount $(\mathrm{kg})$ of NPK fertilizer applied; liming (yes/no); manure addition (yes/no); number of weeding per year; superficial soil management, i.e., soil hoeing (yes/no); coffee pruning (yes/no); and irrigation (yes/no). We also collected data on coffee tree density and coffee production of the previous year $\left(\mathrm{kg} \mathrm{ha}^{-1}\right)$, as recorded by farmers. Most farmers keep records of expenditure, fertilizer addition, and other agricultural activities, and as such, information provided during the interviews 


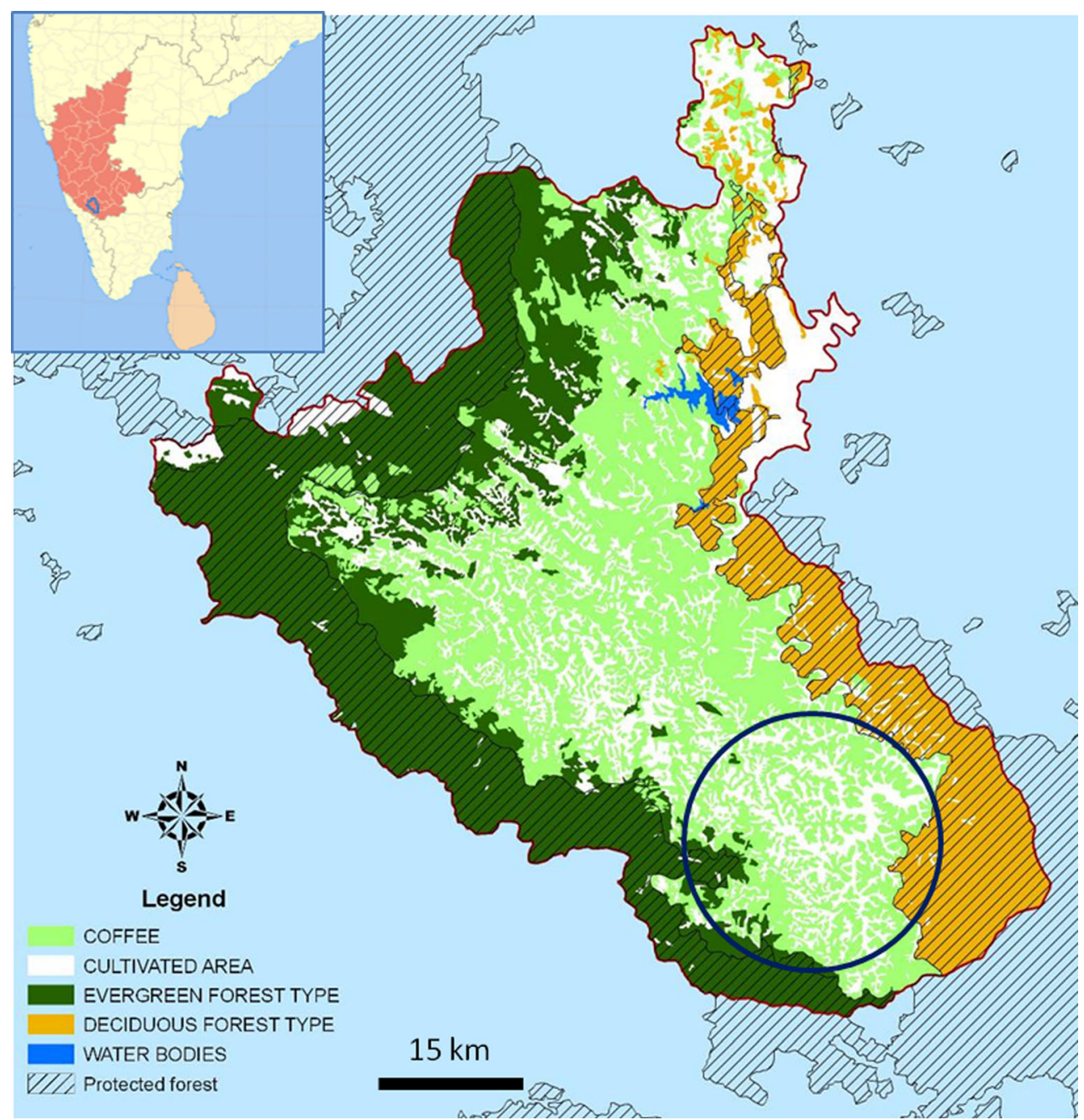

Fig. 2 Map of Kodagu district. The study area is located at the south part of the district (see circle). Source: French Institute of Pondicherry (http://www.ifpindia.org/)

was judged accurate, except for one site, where the reported production was 3.2 standard deviations from the mean. This site was excluded from the dataset as its data were assumed to be unreliable, and analysis was therefore conducted on 112 sites.

\subsection{Shade trees and agroecological characteristics}

On each site, we randomly selected ten Robusta coffee trees along two rows (five sampled trees per row), with every other tree in each row being monitored, and the two monitored rows were separated by one row of coffee trees. Shade was measured at six points around the selected coffee trees by recording the number of obstructed cells in the mirror of a densiometer (Lemmon 1956). We installed two circular plots of 10 -m radius each $\left(2 \times 314 \mathrm{~m}^{2}\right)$, so as to include at least 8 of the 10 selected coffee trees and to allow for the investigation of the direct relationship between local shade tree density and coffee production. The density of shade trees and the individual tree diameter at breast high $(\mathrm{DBH}>10 \mathrm{~cm})$ were recorded within each plot. Trees were separated into two categories: G. robusta and others, the latter category encompassing mostly native tree species.

Soil was sampled 4 to 6 months after the last fertilizer application. In each site, three soil samples were collected, air dried, and mixed thoroughly. Sub-samples of $500 \mathrm{~g}$ were analyzed by Multiplex Biotech Pvt Ltd (Bangalore, India) for $\mathrm{pH}$, organic carbon, and total calcium and by the Krishi Vidyana Kendra Company (Gonikoppal, India) for available $\mathrm{N}$, available $\mathrm{P}$, and available $\mathrm{K}$.

Rainfall data were obtained from 24 farmers who collected such data daily using conventional gauges provided by the Coffee Board of India. From these data, rainfall patterns were interpolated across the region using the inverse distance weighting method (Shepard 1968). The topography of Kodagu varies from approximately 400 to $1800 \mathrm{~m}$, but the geographical area comprising our sites was located in an altitudinal range between 800 and 
$1000 \mathrm{~m}$ (data not shown). We therefore expect our projection to be representative of the actual rainfall patterns.

\subsection{Coffee production}

Production of coffee berries in C. canephora is dependent on cross-pollination, achieved by both wind and insects (Krishnan et al. 2012). In Kodagu, Robusta coffee trees flower once a year toward the end of the dry season between February and March, and eight days after rainfall or irrigation. Prior to flowering, six inflorescences were selected on each of five branches of the ten coffee trees identified per site. The number of buds within inflorescences was counted on each selected branch, and developing berries on the same inflorescences were counted three weeks after flowering (March to early May), before the monsoon (June), at the end of the monsoon (September), and at harvest (December to January). Berry load per infructescence decreased over time, with major drops of coffee berries occurring between March and September. As the drops before March and after September were relatively small, we focused the analysis on the sharp decline between April and June, corresponding to the driest part of the year and between June and September, which covers the monsoon. Berries were harvested and oven dried at $60{ }^{\circ} \mathrm{C}$ for $24 \mathrm{~h}$. We used production per infructescence as a proxy for coffee production. Although it does not take into account resources allocation at the tree level, we could still show competition for resources at this scale and therefore assume that this variable reflects coffee production at the tree scale. Quality was assessed as the proportion of green beans with a size greater than $6.65 \mathrm{~mm}$, which corresponds to the highest quality (grades A and above).

\subsection{Statistical analysis}

We investigated the relationship between management practices, shade, and coffee production (i.e., number and dry weight of individual berries), with linear and generalized linear models using R (The R Project for Statistical Computing). Correlations between independent variables were avoided by removing variables deemed least interesting from the analysis, when such correlations occurred. Due to a hierarchical data structure (multiple inflorescences sampled within trees), we averaged data at tree level and then at site level and included only the averaged values in the statistical models. Models were selected based on the Akaike Information Criteria (AIC) using the MuMIn package, with the best model having the lowest AIC value. Only variables from the final models are presented.

\section{Results and discussion}

\subsection{Management practices, shade trees, and agroecological} characteristics of coffee systems

Robusta coffee in Kodagu is cultivated over several intercorrelated agroecological gradients (e.g., rainfall, shade cover, and shade tree density) and contrasting management practices (e.g., irrigation, liming, NPK fertilization), thus making it a particularly interesting area to study the interplay of agroecological variables, shade cover, and management practices for sustainable agroforestry production. Among our 112 sites, 24 were irrigated to induce flowering, while the rest flowered after rainfall events. The surface of our sites ranged from 0.28 to 32.37 ha. Rainfall in 2008 varied across our sites from 904 to $2577 \mathrm{~mm}$ (mean $=1736 \pm 40(\mathrm{SE})$ ).

All our sites had shade trees, with shade cover varying from $15 \%$ in the most open sites to $76 \%$ in the most shaded sites (mean $=45 \pm 1(\mathrm{SE})$ ). Shade was not correlated with rainfall, probably because they need a permit to fell the trees, even if they do not wish to sell them. Densities of non-Grevillea shade trees varied from 32 to 430 trees $^{-1}{ }^{-1}$ (mean $=190 \pm 9$ (SE)), while G. robusta was present in 60 sites out of 112 , with a density ranging from 16 to 286 trees ha $^{-1}$ (mean $=99 \pm 10$ (SE)). The density of G. robusta was not correlated with the density of non-Grevillea shade trees (correlation of -0.04 , $p=0.67$ ). Shade was correlated neither with the density of non-Grevillea shade trees (correlation of $0.16, p=0.084$ ) nor with that of $G$. robusta (correlation of $0.18, p=0.064$ ). Differences in pruning regimes, leaf flushing, and shedding phenologies might explain this lack of correlation between shade and shade tree densities (Muschler and Wintgens 2009).

In terms of management practices, $63 \%$ of farmers added lime to reduce soil acidity and aluminum toxicity (Rodrigues et al. 2001), and all applied NPK fertilizer. Soil pH varied from 4.5 to 6.3 (mean $=5.5 \pm 0.4(\mathrm{SE})$ ). There was a strong correlation between the amounts of nitrogen $(\mathrm{N})$, phosphorus $(\mathrm{P})$, and potassium $(\mathrm{K})$ applied; therefore, we only considered the amount of $\mathrm{N}$ input as a proxy for the overall fertilization. The amount of $\mathrm{N}$ applied by farmers ranged from 62 to $316 \mathrm{~kg} \mathrm{ha}^{-1}$ year $^{-1}$ (mean $=137 \pm 4(\mathrm{SE})$ ). All farmers manually weeded their plantations, except at two sites, where herbicide was used. Manure addition was done by $43 \%$ of the farmers, while soil hoeing was carried out in $53 \%$ of the sites. All farmers pruned their coffee trees in a similar manner; hence, pruning was not included in the analysis.

\subsection{Relative impact of management practices and shade trees on coffee production}

The number of coffee flowers per inflorescence directly and substantially affected the number of mature berries, with an additional mature berry for every additional ten flowers per 
inflorescence. Across all sites (Fig. 3), the average number of flowers per inflorescence was $34.7 \pm 0.38$ (SE) and was positively correlated with lime application and superficial soil hoeing but negatively influenced by available N. Shade had no effect on flower production, so, within physiological limits, farmers could therefore increase final fruit set by increasing flower production through lime application and soil hoeing regardless of shade cover management. Both soil liming and hoeing increased flower number per inflorescence by 1.8 on average, representing a $5.4 \%$ increase for each practice. The widely adopted practice of soil hoeing reduces crust formation of the top soil, which facilitates water infiltration. Since coffee flowering is triggered by water, soil permeability enhanced by surface digging might promote coffee flowering. This in itself might explain why the number of flowers is positively affected by this agricultural practice. On the other hand, the amount of available $\mathrm{N}$ in the soil reduced flowers per inflorescence by an average of $2.5(7 \%)$ per $100 \mathrm{~kg} \mathrm{ha}^{-1}$ of available $\mathrm{N}$ within the range of 321 to $534 \mathrm{~kg} \mathrm{ha}^{-1}$. As available $\mathrm{N}$ and $\mathrm{N}$ input are not correlated, available $\mathrm{N}$ in the soil probably reflects differences in soil organic matter content and mineralization.

Between April and June in the early phase of coffee berry development, the loss of berries per infructescence was greater with higher initial fruit set ( 1.7 berry losses with each 5 additional initial fruits), as well as with higher densities of G. robusta $(0.9$ or $17.5 \%$ berry losses for 100 additional G. robusta trees) and coffee trees ( 2.1 or $36.6 \%$ berry losses for each additional 500 coffee trees). Increasing rainfall, irrigation, and manure application all increased the retention of developing coffee berries, respectively, by 1.8 or $16.5 \%$ per $500 \mathrm{~mm}$ of rainfall, 5.6 or $50.8 \%$ with irrigation, and 1.8 or $20 \%$ with manure addition (Table 1). Between June and September, coffee berry losses were greater with higher initial fruit set ( 2.4 berry losses with each 5 additional fruits) and lower with increasing shade (Fig. 4a) and lime application $(-1.9$ or $-21.3 \%$ berries lost with lime application) (Table 1$)$.

At harvest in December, infructescences bore an average of $12.9 \pm 0.34$ (SE) berries (Fig. 3). Coffee production, as the average number of berries produced per infructescence, was positively related to the initial number of flowers ( 1.0 or $8.6 \%$ berry increase for 10 additional flowers), lime application ( 2.3 or $20 \%$ berry increase), irrigation ( 1.9 or $16 \%$ berry increase), and the density of non-Grevillea shade trees $(0.6$ or $5.6 \%$ berry increase for 100 additional non-Grevillea trees). Rainfall on the flowering day had a negative influence on coffee production $(-2.8$ or $-20 \%$ berry decrease) (Table 1$)$, while shade had no impact at all (Fig. 4b). The average dry berry weight was $0.510 \mathrm{~g} \pm 0.009$ (SE), was negatively influenced by the number of berries produced $(-0.1 \mathrm{~g}$ or $-19.6 \%$ per 10 additional berry) and coffee tree density $(-0.008 \mathrm{~g}$ or $-1.6 \%$ per 100 additional coffee trees), and was positively influenced by the number of weedings per year $(0.1 \mathrm{~g}$ or $25.6 \%$ ). The proportion of large green beans was positively and significantly influenced by the density of non-Grevillea shade trees $(6.25 \%$ more green beans above $6.65 \mathrm{~mm}$ per additional 100 non-Grevillea trees) and the soil available phosphate.

The retention of berries before and during the monsoon, as well as the dry weight of individual berries, appeared to benefit from reduced competition for resources. For instance, berry loss before the monsoon increased with berry number, density of coffee trees, and density of $G$. robusta, while application of manure and water (irrigation and rainfall) played an important role in retaining berries. Berry losses are reduced by $20 \%$ with manure, $51 \%$ with irrigation, and $55 \%$ by rainfall regime. Irrigation still contributed to $16 \%$ of the number of harvested berries. Shade, although reducing berry losses during early berry development, did not affect coffee production over a range of shade values from 15 to $76 \%$. This result differs from an earlier study in Mexico which showed that highest coffee production occurred under shade cover ranging from 22 to $50 \%$ (Soto-Pinto et al. 2000), although this study provided little information on other management interventions (e.g., fertilizer application, weeding).

NPK fertilization did not significantly affect coffee production in Kodagu, which is contrary to results reported in other coffee regions (Cervellini et al. 1994; Prezotti and Da Rocha 2004). This could be due to efficient nutrient recycling via leaf litter of shade trees, whose densities are generally much higher in Kodagu than other coffee growing regions (Boreux et al. 2013a). This certainly implies that farmers in Kodagu could reduce fertilizer inputs without any negative impact on coffee production. A similar trend has already been documented for C. arabica in Costa Rica, where less than $50 \%$ of total N applied was used by coffee (Salas et al. 2002). While there was no evidence that fertilizer application affected coffee production, agricultural practices increasing the capacity of coffee trees to take up nutrients did benefit coffee production. For instance, lime application (which raises $\mathrm{pH}$ ) contributed to increasing the number of harvested berries per infructescence by $20 \%$, while weeding (which reduces nutrient competition between coffee trees and weeds) and a lower coffee tree density resulted in an increased dried weight per berry by 26 and $18 \%$, respectively. Berry losses before and during the monsoon and final dry weight of berries were all affected by berry number, reflecting competition among berries for limited resources at the plant level (Cannel 1985). Therefore, branch pruning, systematically undertaken by farmers, appears as a meaningful practice to adjust coffee berry load at the plant level.

\subsection{The impact of canopy diversity on coffee production}

The retention of trees in agroforestry systems has been the focus of much recent research both in terms of the direct benefits provided to the crop as well as the ecosystem services 
Coffee load per inflorescence across one growing season

Fruit load per inflorescence

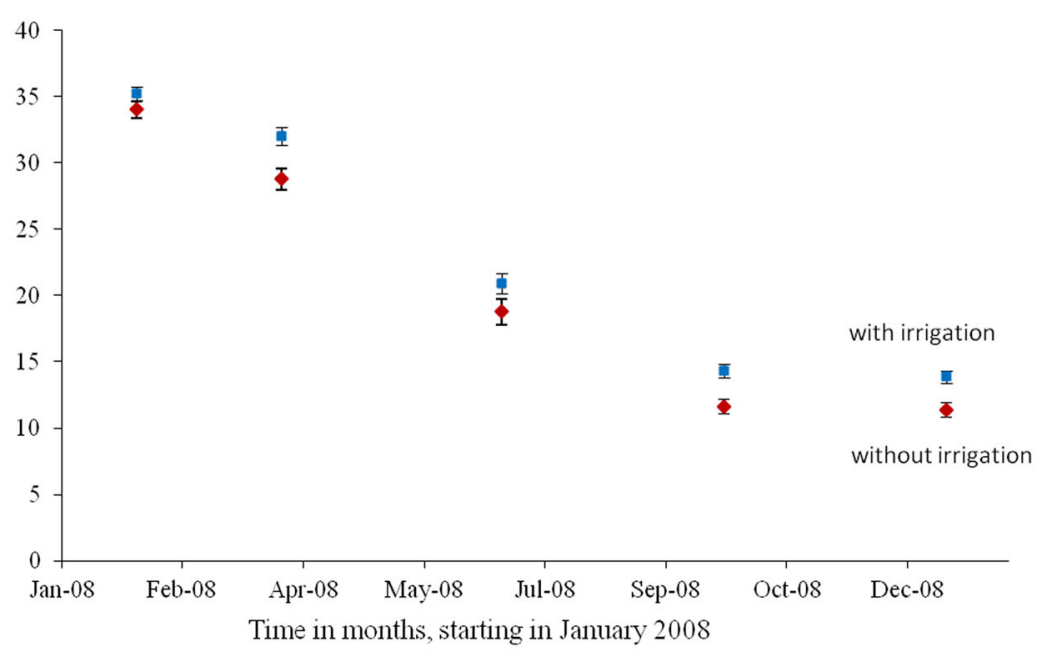

(b) sites with and without lime application
Fruit load per inflorescence

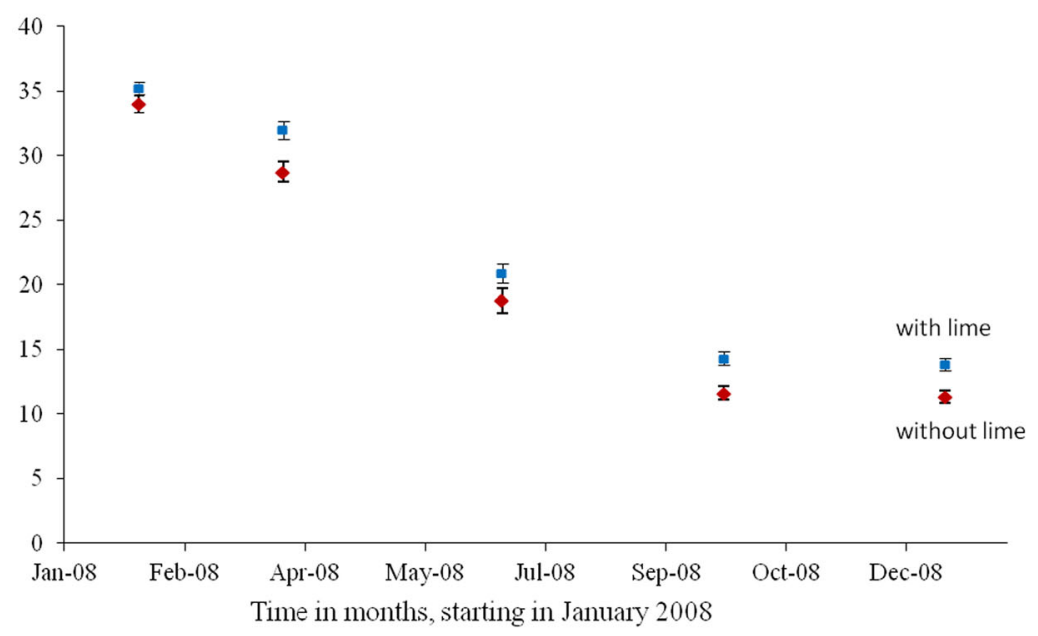

Fig. 3 Evolution of flower and berry number per inflorescence/ infructescence across the 2008-growing season in a irrigated (squares) versus non-irrigated (diamonds) sites and $\mathbf{b}$ sites where lime was applied (squares) versus sites where no lime was applied (diamonds). Flowers

they support (Perfecto et al. 2007), but few studies have investigated the relative impact of native, complex, and diverse canopies versus monospecific, exotic ones in agroforestry production. In Kodagu, very few plantations were shaded exclusively by $G$. robusta, except those recently established and not yet in production at the time of this study. Thus, it was not possible to quantify the effects of a pure stand of $G$. robusta on coffee production. Grevillea and non-Grevillea shade trees do, however, differ in their effects on coffee production. For instance, the density of G. robusta increased pre-monsoon berry losses by 0.9 berries per infructescence (i.e., $1.7 \%$ ) for each 100 additional $G$. robusta per hectare (Table 1), while non- were counted in February, while berries were counted in April, June, October, and at the time of harvest in December. Loads per inflorescence/infructescence are averaged across the 112 sites, and standard errors are shown for each average

Grevillea shade tree density did not influence berry losses. This negative impact might be explained by the fact that G. robusta might compete more than the other tree species with coffee trees for water (as Lott et al. 2000 showed for maize) and/or nutrients, hence affecting the retention rate of berries. By contrast, the density of non-Grevillea shade trees was positively, although not strongly, correlated with coffee production, with an average berry production increase of $5.6 \%$ per 100 trees ha $^{-1}$ added across the range of 32 to 430 trees ha ${ }^{-1}$ (Table 1).

Shade trees can reduce water and heat stress within coffee plantations by creating a microclimate in the understory 
Table 1 Effects of shade tree densities (non-Grevillea and Grevillea), coffee tree density, shade, management practices, and environmental variables on different coffee production variables

\begin{tabular}{|c|c|c|c|c|c|}
\hline Final models & Estimate & Std. error & $F$ value & $t$ value & $\operatorname{Pr}(>|t|)$ \\
\hline \multicolumn{6}{|c|}{ Dependent variable: loss of coffee berries before the monsoon $\left(\mathrm{DF}=89, R^{2}=0.43\right)$} \\
\hline (Intercept) & 1.69 & 3.43 & & 0.49 & 0.62 \\
\hline Initial fruit & 0.33 & 0.07 & 20.7 & 4.55 & $<0.001$ \\
\hline Irrigation & -5.57 & 0.98 & 32.6 & -5.71 & $<0.001$ \\
\hline Density of Grevillea shade trees & 0.01 & 0.004 & & 2.30 & 0.024 \\
\hline Density of non-Grevillea shade trees & 0.008 & 0.004 & 3.2 & 1.78 & 0.078 \\
\hline Density of coffee trees & 0.004 & 0.002 & 5.6 & 2.37 & 0.020 \\
\hline Rainfall until June 2008 & -0.004 & 0.001 & 14.7 & -3.83 & $<0.001$ \\
\hline Manure application & -1.81 & 0.80 & 5.1 & -2.25 & 0.027 \\
\hline \multicolumn{6}{|c|}{ The full model also included the following variables: soil $\mathrm{pH}$, lime application, shade, and $\mathrm{N}$ input } \\
\hline \multicolumn{6}{|c|}{ Dependent variable: loss of coffee berries during the monsoon $\left(\mathrm{DF}=89, R^{2}=0.62\right)$} \\
\hline (Intercept) & 0.45 & 1.40 & & 0.32 & 0.75 \\
\hline Initial fruit & 0.48 & 0.04 & 112.5 & 10.60 & $<0.001$ \\
\hline Shade & -0.05 & 0.02 & 7.0 & -2.65 & 0.010 \\
\hline Lime application & -1.88 & 0.49 & 14.6 & -3.82 & $<0.001$ \\
\hline \multicolumn{6}{|c|}{$\begin{array}{l}\text { The full model also included the following variables: soil } \mathrm{pH} \text {, irrigation, coffee tree density, density of non-Grevillea shade trees, density of Grevillea } \\
\text { shade trees, N input, soil pH, rainfall until September 2008, and manure application }\end{array}$} \\
\hline \multicolumn{6}{|c|}{ Dependent variable: coffee production $\left(\mathrm{DF}=100, R^{2}=0.36\right)$} \\
\hline (Intercept) & -4.10 & 5.10 & & -0.80 & 0.42 \\
\hline Number of flowers & 0.21 & 0.08 & 7.4 & 2.71 & 0.008 \\
\hline Density of non-Grevillea shade trees & 0.006 & 0.003 & 4.2 & 2.05 & 0.043 \\
\hline Lime application & 2.31 & 0.60 & 14.6 & 3.82 & $<0.001$ \\
\hline $\mathrm{pH}$ & 1.27 & 0.84 & & 1.51 & 0.13 \\
\hline Irrigation & 1.90 & 0.70 & 7.3 & 2.70 & 0.008 \\
\hline Rain on the flowering day & -2.76 & 0.83 & 11.0 & -3.32 & 0.001 \\
\hline
\end{tabular}

The full model also included the following variables: density of coffee trees, shade, density of Grevillea shade trees, $\mathrm{N}$ input, soil organic carbon, and manure application

The summaries of linear model analyses are presented after model reduction. Adjusted $R^{2}$ values are in parentheses after the name of the dependent variable tested. Other variables included in the full model and not appearing after model reduction are listed after each analysis

through the buffering of temperature (Souza et al. 2012) and relative humidity extremes (Lin 2010). Developing berries are susceptible to water and heat stress, especially during their early development stage. In India, this critical stage falls at the end of the dry season between March and June. Shade cast by a $G$. robusta dominated canopy is very different to the one cast by a non-Grevillea complex and diverse canopy (Fig. 1), not only because the pruning regime differs but also due to the tree architecture and the open leaf structure of G. robusta. With a higher competition for resources (i.e., soil water), on the one hand, and a lesser amount of shade, on the other hand, we thus expected a $G$. robusta dominated canopy to increase the stress linked to water and heat. We did not observe a significant impact of $G$. robusta on coffee production and cannot therefore reject the null hypothesis. Water and heat stress, however, become critical for coffee trees in years, when the onset of rainfall is delayed and with a prolonged dry season (Cannavo et al. 2011). As rainfall was not delayed during our study period, the timely abundance of water might have hidden any inefficiency of G. robusta in alleviating water and heat stress for the coffee trees, suggesting avenues for further research.

With regard to the quality of coffee, the proportion of higher quality beans was strongly and positively influenced by the density of non-Grevillea shade trees but not by that of G. robusta.

Our work indicates that $G$. robusta has either a negative or no impact on coffee production and quality, whereas a complex and diverse canopy has a positive impact. This result corresponds with farmers' knowledge and observations in the field, as they reported during interviews that production from individual coffee trees growing under G. robusta was lower. They argue that this is due to the bi-pinnate leaves of $G$. robusta, which fall on coffee trees and cover developing berries, coupled with the very slow decomposition of these leaves. If true, then extensive conversion of shade trees to a pure $G$. robusta stand might adversely affect the development of coffee berries. We expect this to be 


\section{Impact of shade}

(a) Loss of coffee berries during the monsoon

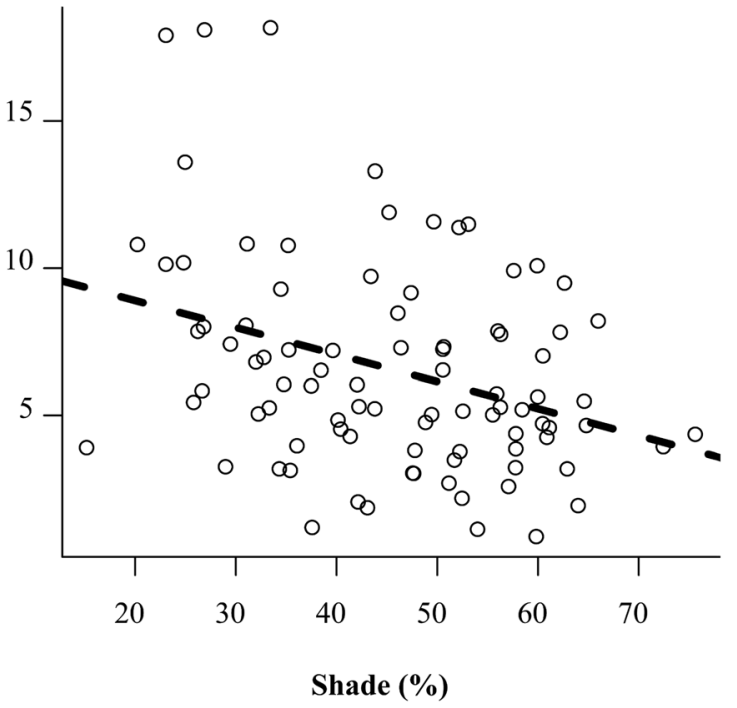

(b) Number of coffee berries at harvest

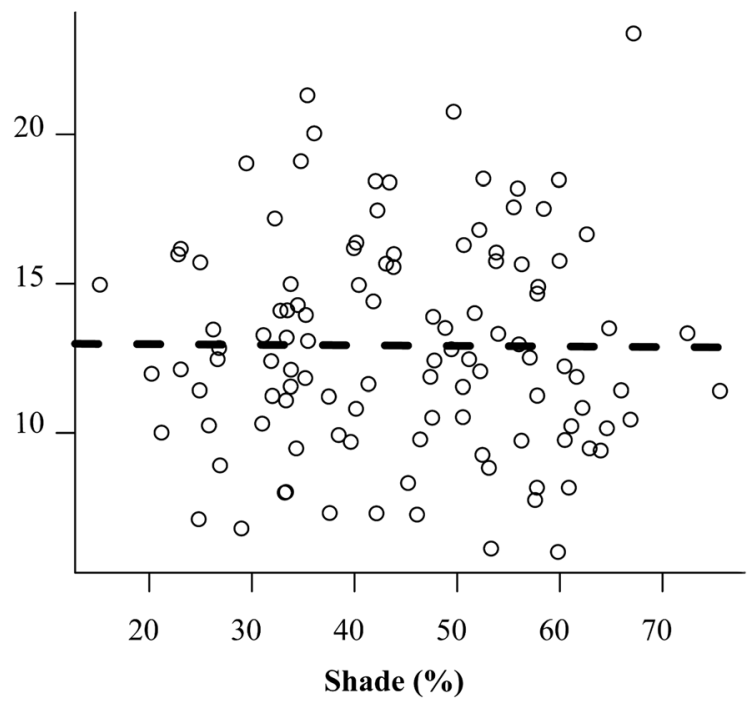

Fig. 4 Impact of shade (in percent) on a the loss of coffee berries (in berries per infructescence) during the monsoon season and $\mathbf{b}$ the number of coffee berries (per infructescence) at the time of harvest

particularly important when rain is delayed and suggest that further research should be undertaken to explore the interaction between canopy composition and delayed rains.

Despite these perceived agronomic drawbacks, farmers overwhelmingly plant $G$. robusta in preference to other species owing to the particular tree rights situation in Kodagu. To legally remove and sell most tree species, farmers have to undergo a long and arduous permit application process (Garcia et al. 2010). On the other hand, G. robusta is free from such restrictions and, as such, is much easier to manage and market. This, along with the fact that $G$. robusta has a short rotation (20 years) and makes good stands for pepper vines, explains why an increasing number of farmers favor $G$. robusta over the other species, particularly in newly established plantations (Garcia et al. 2010; Nath et al. 2011). The ecosystem services provided by the complex and biodiversity rich canopy cover does not seem to compensate these factors in the eyes of the farmers. Strategies advocating the conservation of biodiversity in coffee plantations must take this mismatch into account, lest they fail to address the real drivers of change in the system.

\section{Conclusion}

Sustainable coffee production in agroforest systems requires a thorough understanding of management practices, their interactions with the local agroecological context, and their impact on the provision of ecosystem services. This study demonstrates that agricultural practices differ substantially in their coffee production outcomes, and that they can have multiple and often interacting effects. While recent studies in agroforestry contexts have placed much emphasis on shade cover and shade tree density, it should also be recognized that other management interventions might more effectively benefit crop production, while affecting the provision of ecosystem services. This implies that farm productivity and biodiversity conservation objectives might only be partially aligned within agroforestry systems. Retaining shade trees in complex and diverse canopies makes perfect sense for biodiversity conservation and the provision of ecosystem services. Management interventions, however, offer alternatives that can decouple production from the supporting and regulating services provided by biodiversity. For practices to change and biodiversity to become a management objective, farmers will need more than awareness rising. A different set of incentives, subsidies such as payments for ecosystem services (PES) and a change in values from both producers and consumers is required. For now, most of the coffee farmers in Kodagu have retained a dense shade with multiple species. Plantations with low density of shade trees probably benefit from such surrounding plantations (see also Boreux et al. 2013b). However, as an increasing number of farmers shift toward more open plantations and G. robusta dominated canopies, coffee production at the landscape scale might suffer damaging losses for farmers' livelihoods. An indepth assessment of the relative value of $G$. robusta and the other tree species, taking into consideration the benefits from timber and non-timber forest products (e.g., fruits), as well as the ecosystem services provision (e.g., nutrient cycling, carbon sequestration, pest and disease control, pollination, and microclimate buffering), is required to assert with certainty the best management options for optimal and sustainable coffee production both at the plantation and landscape scale. 
Acknowledgments We are grateful to the coffee farmers that participated in this study and thank them for their support and involvement. We would also like to thank the many field assistants who participated tirelessly in data collection, as well as Prof. Harald Bugmann for his useful comments on this manuscript. Support for this study was provided by the ZIL (Swiss Centre for International Agriculture, Zürich, Switzerland) and the Professorship of Ecosystem Management, ETH Zürich. Prof. Uma Shaanker provided invaluable support throughout the study. This work was done in collaboration with the Managing Biodiversity in Mountain Landscapes project of the French Institute of Pondicherry and the CAFNET project financed by the European Commission.

\section{References}

Beer J, Muschler R, Kass D, Somarriba E (1998) Shade management in coffee and cacao plantations. Agrof Syst 38:139-164. doi:10.1007 1978-94-015-9008-2 6

Boreux VE, Cheppudira KG, Vaast P, Ghazoul J (2013a) Interactive effects among ecosystem services and management practices on crop production: Pollination in coffee agroforestry systems. Proc Natl Acad Sci U S A 110:8387-8392. doi:10.1073/pnas.1210590110

Boreux VE, Krishnan S, Cheppudira KG, Ghazoul J (2013b) Impact of forest fragments on bee visits and fruit set in rain-fed and irrigated coffee agro-forests. Agric Ecosyst Environ 172:42-48. doi:10.1016/j. agee.2012.05.003

Borkhataria R, Collazo JA, Groom MJ, Jordan-Garcia A (2012) Shadegrown coffee in Puerto Rico: opportunities to preserve biodiversity while reinvigorating a struggling agricultural commodity. Agric Ecosyst Environ 149:164-170. doi:10.1016/j.agee.2010.12.023

Campanha MM, Santos RHS, de Freitas GB, Martinez HEP, Garcia SLR, Finger FL (2005) Growth and yield of coffee plants in agroforestry and monoculture systems in Minas Gerais, Brazil. Agrof Syst 63:75-82. doi:10.1023/B:AGFO.0000049435.22512.2d

Cannavo P, Sansoulet J, Harmand JM, Siles P, Dreyer E, Vaast P (2011) Agroforestry associating coffee and Inga densiflora results in complementarity for water uptake and decreases deep drainage in Costa Rica. Agric Ecosyst Environ 140:1-13. doi:10.1016/j.agee.2010.11.005

Cannel MGR (1985) Physiology of the coffee crop. In: Helm CNaWKC (Ed.) Coffee: botany, biochemistry and production of beans and beverage, London, pp. 108-134. doi: 10.1007/978-1-4615-6657-1_5

Cervellini GDS, Igue T, Toledo SVD (1994) Liming and mineral and organic fertilization of coffee tree at Campinas region, State of Sao Paulo, Brazil. Bragantia 53:273-280. doi:10.1590/S0006-87051994000200018

Garcia CA, Bhagwat SA, Ghazoul J, Nath CD, Konerira MN, Cheppudira KG, Raghuramulu Y, Nasi R, Vaast P (2010) Biodiversity conservation in agricultural landscapes: challenges and opportunities of coffee agroforests in the Western Ghats, India. Conserv Biol 24:479-488. doi:10.1111/j.1523-1739.2009.01386.x

Harvey CA, Komar O, Chazdon R, Ferguson BG, Finegan B, Griffith DM, Martinez-Ramos M, Morales H, Nigh R, Soto-Pinto L, Van Breugel M, Wishnie M (2008) Integrating agricultural landscapes with biodiversity conservation in the Mesoamerican hotspot. Conserv Biol 22:8-15. doi:10.1111/j.1523-1739.2007.00863.x

Kellermann JL, Johnson MD, Stercho AM, Hackett SC (2008) Ecological and economic services provided by birds on Jamaican blue mountain coffee farms. Conserv Biol 22:1177-1185. doi:10.1111/j.15231739.2008.00968.x

Kitti M, Heikkila J, Huhtala A (2009) 'Fair' policies for the coffee tradeprotecting people or biodiversity? Environ Dev Econ 14:739-758. doi:10.1017/s1355770x09005208

Klein AM, Steffan-Dewenter I, Tscharntke T (2003) Pollination of Coffea canephora in relation to local and regional agroforestry management. J Appl Ecol 40:837-845. doi:10.1046/j.1365-2664.2003.00847.x
Krishnan S, Kushalappa CG, Uma Shaanker R, Ghazoul J (2012) Status of pollinators and their efficiency in coffee production in a fragmented landscape mosaic in South India. Basic Appl Ecol 13:277-285. doi:10.1016/j.baae.2012.03.007

Lemmon PE (1956) A spherical densiometer for estimating forest overstory density. For Sci 2:314-320

Lin BB (2010) The role of agroforestry in reducing water loss through soil evaporation and crop transpiration in coffee agroecosystems. Agric For Meteorol 150:510-518. doi:10.1016/j.agrformet.2009.11.010

Lott JE, Howard SB, Ong CK, Black CR (2000) Long-term productivity of a Grevillea robusta-based overstorey agroforestry system in semi-arid Kenya: II. Crop growth and system performance. For Ecol Manag 139:187-201. doi:10.1016/S0378-1127(00)00266-8

Mas AH, Dietsch TV (2003) An index of management intensity for coffee agroecosystems to evaluate butterfly species richness. Ecol Appl 13: 1491-1501. doi:10.1890/01-5229

Muschler RG, Wintgens JN (2009) Shade management and its effect on coffee growth and quality. In: Wintgens JN (Ed.) Coffee: growing, processing, sustainable production. A guidebook for growers, processors, traders and researchers. Wiley-VCH Verlag GmbH, pp. 395-422. doi: 10.1002/9783527619627.ch14

Nath C, Pélissier R, Ramesh B, Garcia C (2011) Promoting native trees in shade coffee plantations of southern India: comparison of growth rates with the exotic Grevillea robusta. Agroforest Syst:1-13. doi: 10.1007 /s10457-011-9401-8

Perfecto I, Rice RA, Greenberg R, VanderVoort ME (1996) Shade coffee: a disappearing refuge for biodiversity. Bioscience 46:598-608. doi: $10.2307 / 1312989$

Perfecto I, Vandermeer J, Hanson P, Cartin V (1997) Arthropod biodiversity loss and the transformation of a tropical agro-ecosystem. Biodivers Conserv 6:935-945. doi:10.1023/A:1018359429106

Perfecto I, Armbrecht I, Philpott SM, Soto-Pinto L, Dietsch TV (2007) Shaded coffee and the stability of rainforest margins in northern Latin America. In: Tscharntke T, Leuschner C, Zeller M, Guhardja E, Bidin A (eds) Stability of tropical rainforest margins: linking ecological, economic and social constraints of land use and conservation. Springer, Berlin, pp 227-263

Prezotti LC, Da Rocha AC (2004) Coffee nutrition as a function of plant density and NPK fertilization. Bragantia 63:239-251. doi:10.1590 /S0006-87052004000200009

Rodrigues LA, Martinez HEP, Neves JCL, Novais RF, Mendonca SM (2001) Growth response of coffee tree shoots and roots to subsurface liming. Plant Soil 234:207-214. doi:10.1023/A:1017999318532

Salas R, Bornemisza E, Zapata F, Chaves V, Rivera A (2002) Absorcion del fertilizante nitrogenoda per la planta de cafe y su influencia sobre la contaminacion de las aguas subterraneas. In: R-V J (ed) Manejos integrado de aguas subterraneas. EUNED, San Jose, pp 89-104

Shepard D (1968) A two-dimensional interpolation function for computer mapping of irregularly spaced data. In: ACM (Ed.) Proceedings of the 1968 23rd ACM national conference, pp. 517-524

Somarriba E, Harvey CA, Samper M, Anthony F, Gonzalez J, Staver C, Rice RA (2004) Biodiversity conservation in neotropical coffee (Coffea arabica) plantations. In: Schroth G, Fonesca GAB, Harvey CA, Gascon C, Vasconcelos HL, Izac AMN (eds) Agroforestry and biodiversity conservation in tropical landscapes. Island Press, Washington, pp 198-226

Soto-Pinto L, Perfecto I, Castillo-Hernandez J, Caballero-Nieto J (2000) Shade effect on coffee production at the northern Tzeltal zone of the state of Chiapas, Mexico. Agric Ecosyst Environ 80:61-69. doi:10.1016/S0167-8809(00)00134-1

Souza HND, de Goede RG, Brussaard L, Cardoso IM, Duarte EM, Fernandes R, Gomes LC, Pulleman MM (2012) Protective shade, tree diversity and soil properties in coffee agroforestry systems in the Atlantic Rainforest biome. Agric Ecosyst Environ 146:179-196. doi:10.1016/j.agee.2011.11.007 